\title{
MEKANISASI SISTEM PANEN PADA KULTUR MASSAL ROTIFER, Brachionus rotundiformis
}

\author{
Inneke F.M. Rumengan*), Budiyanto**), Rinny Modaso*), Didit Dewanto**), \\ dan Daniel Limbong**) \\ *) Fakultas Perikanan dan IImu Kelautan, Universitas Sam Ratulangi \\ Kampus UNSRAT, Bahu Manado 95115 \\ E- mail: inneke0511@gmail.com \\ *) Program Studi IImu Perairan Pasca Sarjana Universitas Sam Ratulangi, \\ Manado 95115 \\ ***) Pusat Penelitian Wilayah Pesisir, Poigar, \\ Kabupaten Minahasa Selatan
}

(Naskah diterima: 21 Maret 2011; Disetujui publikasi: 16 Februari 2012)

\begin{abstract}
ABSTRAK
Rotifer adalah salah satu jenis zooplankton yang populer dimanfaatkan sebagai pakan alami untuk pemeliharaan Iarva fauna air. Beberapa kajian dewasa ini juga mempromosikan rotifer sebagai sumber senyawa bioaktif seperti khitin. Salah satu permasalahan utama dalam upaya pemanfaatan rotifer untuk akuakultur maupun untuk memproduksi senyawa bioaktif, adalah ketidakberlanjutan dan rendahnya produksi rotifer. Berdasarkan eksperimen di laboratorium menyangkut biologi dan ekologi rotifer, kultur massal yang intensif telah berhasil dilakukan pada kolam beton berukuran panjang $5 \mathrm{~m}$, lebar $1 \mathrm{~m}$, dan dalam $1 \mathrm{~m}$. Teknik panen dan hal lain yang terkait, dipandang sebagai faktor penting yang mempengaruhi keberhasilan sistem kultur massal tersebut. Mengacu pada beberapa aspek teknik yang sedang dijalankan, studi ini dilakukan untuk memperbaiki mekanisasi teknik pemanenan yang diharapkan akan meningkatkan efektivitas produksi biomassa rotifer yang bermutu baik. Beberapa uji penerapan dari hasil mekanisasi teknik pemanenan, menampilkan kapasitasnya dalam memperbaiki mutu produksi rotifer, mereduksi waktu panen dan tenaga kerja, serta mempertahankan kontinuitas siklus produksi.
\end{abstract}

KATA KUNCl: rotifer, kultur massal, teknik pemanenan

ABSTRACT : Harvest technique of the rotifer mass production system. By: Inneke F.M. Rumengan, Budiyanto, Rinny Modaso, Didit Dewanto, and Daniel Limbong

Rotifer is one of the most popular zooplankton which used as life food for larva cultivation of aquatic animals. Recent studies have also been promoting rotifer as potential source of bio-active substance such as chitine. One of the major problems for better use of rotifer in aquaculture as well as in bio-active substance production is the discontinuity and insufficient of rotifer production. Based on laboratory experimental studies on rotifer biology and ecology, an intensive mass culture was effectively carried out in $5 \mathrm{~m}$ length, $1 \mathrm{~m}$ width, $1 \mathrm{~m}$ depth of concrete ponds. The harvest technique and its inherent practicability is regarded as a significant factor influencing the success of the rotifer mass production system. Looking at various aspects of the current harvest practices, the present study was conducted to improve mechanical 
aspects of the harvest technique and in turn to promote the effectiveness of production of good quality rotifer biomass. Several trials of the new mechanical harvest technique demonstrated its ability to improve the quality of rotifer production, to reduce the harvest time and labor, and to maintain adequate production cycle.

\section{KEYWORDS: rotifer, mass culture, harvest technique}

\section{PENDAHULUAN}

Rotifer adalah salah satu organisme laut yang termasuk kelompok zooplankton, dan sejak tahun 1960- an telah populer di kalangan peneliti dan praktisi akuakultur, sebagai pakan hidup larva fauna air (Lubzens et al., 1989; Nogrady et al., 1993). Sebanyak 10 spesies rotifer telah ditemukan di perairan pantai Sulawesi Utara, dan spesies Brachionus rotundiformis telah menjadi objek penelitian pada Laboratorioum Bioteknologi Kelautan, Fakultas Perikanan dan IImu Kelautan, Universitas Sam Ratulangi sejak tahun 1994 (Yoshinaga et al., 2004; Rumengan et al., 1998). Perhatian terhadap potensi molekuler rotifer juga telah mendorong peningkatan penelitian pemanfaatannya untuk industri farmasi (Klusemann et al., 1990; Suga et al., 2007; Rumengan, 1997; Wallace \& Snell, 1991; Bowman et al., 1990; Hara et al., 1984).

Kebutuhan biomassa rotifer baik untuk pakan larva fauna air pada industri akuakultur, maupun untuk ekstrasi senyawa farmasetika, relatif besar dan harus tersedia secara kontinu. Pengembangan dan peningkatan sistem kultur massal rotifer, diharapkan dapat menghadirkan teknologi penyedia bahan baku rotifer. Masalah yang perlu mendapat perhatian dalam pengembangan ini adalah:

1) Metode atau teknik panennya, karena sangat berpengaruh pada kontinuitas sistem kultur, efektivitas dan efisiensi pemanenan, serta kualitas biomassa rotifer yang dihasilkan.

2) Penetapan waktu dan jumlah panen agar produksi yang optimal dapat diperoleh secara kontinu.

Serangkaian uji coba kultur massal kontinu dengan sistem yang berbasis kolam pekarangan (out door pond) berukuran $5 \mathrm{mx}$ $1 \mathrm{~m}$ dan tinggi $1 \mathrm{~m}$, dengan input air laut 31 ppt, benih inokulan rotifer Brachionus rotundiformis, dan ikan mentah sebagai bahan untuk memperkaya medium kultur rotifer, memberikan hasil yang menjanjikan. Tingkat produksi rotifer sebesar $200-500$ g/ kolam/ bulan dapat dicapai melalui ujicoba tersebut. Kajian yang difokuskan pada kedua masalah tersebut di atas telah berhasil dilakukan, dan capaiannya diuraikan dalam tulisan ini.

\section{BAHAN DAN METODE}

Penelitian pengembangan kultur massal rotifer dilaksanakan pada kolam pekarangan Pusat Penelitian Wilayah Pesisir di Poigar Kabupaten Minahasa Selatan, sejak bulan Februari sampai Desember 2010. Kolam beton yang digunakan berukuran panjang $5 \mathrm{~m}$, lebar $1 \mathrm{~m}$, dan tinggi $1 \mathrm{~m}$. Kolam diisi dengan air laut bersalinitas 31 ppt yang dipompa dari pantai Teluk Poigar. Kedalaman air dalam kolam dipertahankan pada posisi $80 \mathrm{~cm}$. Benih inokulan rotifer Brachionus rotundiformis, sebanyak lebih kurang 600.000 individu diperoleh dari tambak di Desa Tiberias Kabupaten Bolaang Mongondow. Kontinuitas sistem kultur diupayakan dengan meng- inputkan sekali dalam 2 minggu, 1 kg ikan mentah ke dalam kolam. Hal ini bertujuan agar hasil penguraian pada proses pembusukan ikan tersebut membentuk medium yang baik bagi pertumbuhan rotifer.

Hasil kultur rotifer dipanen dengan cara menyaring medium kulturnya dengan jaring plankton berukuran mata 20-40 $4 \mathrm{~m}$, karena ukuran rata- rata lebar lorica rotifer dalam keadaan normal adalah $80 \mu \mathrm{m}$, dan dalam keadaan tertekan bisa mengecil sampai sekitar $30 \mu \mathrm{m}$. Dalam upaya menghadirkan teknik panen yang optimal, tiga cara pemanenan diterapkan secara trial and error, yaitu:

1) Memompa medium kultur dengan pompa celup dan menyaringnya untuk mendapatkan rotifer (Gambar 1A)

2) Menarik jaring plankton secara horizontal dan berulang-ulang pada lapisan permukaan kolam (Gambar 1B)

3) Menyifon (menyedot) lapisan permukaan dan menyaringnya (Gambar 1C)

Untuk memfasilitasi pengembangan metode penetapan waktu dan jumlah panen yang optimal, dilakukan pemantauan kepa- 
datan rotifer dengan interval 4- 8 jam. Data tersebut digunakan untuk memprediksi fluktuasi kepadatan rotifer berdasarkan model pertumbuhan logistik (Verhulst, 1838 dalam Clark, 1976) yang dirumuskan sebagai berikut:

$$
\mathrm{P}_{\mathrm{t}}=\mathrm{P}_{\mathrm{m}} /\left\{1+\mathrm{e}^{-\mathrm{r}(\mathrm{t}-\mathrm{t})}\right\}
$$

$\mathrm{P}_{\mathrm{t}}$ adalah kepadatan rotifer pada waktu $t, \mathrm{P}_{\mathrm{m}}$ adalah daya dukung (carrying capacity), $r$ adalah koefisien pertumbuhan (intrinsic rate of increase), dan ti adalah konstanta. Parameter model pertumbuhan (Pm, $r$, dan ti) tersebut dihitung dengan mengikuti prosedur (Pauly, 1984). Parameter $P_{m}$ ditetapkan dengan cara merata- ratakan beberapa nilai kepadatan maksimum yang pernah diamati. Selanjutnya, dengan menggunakan bentuk linier dari model pertumbuhan logistik di atas:
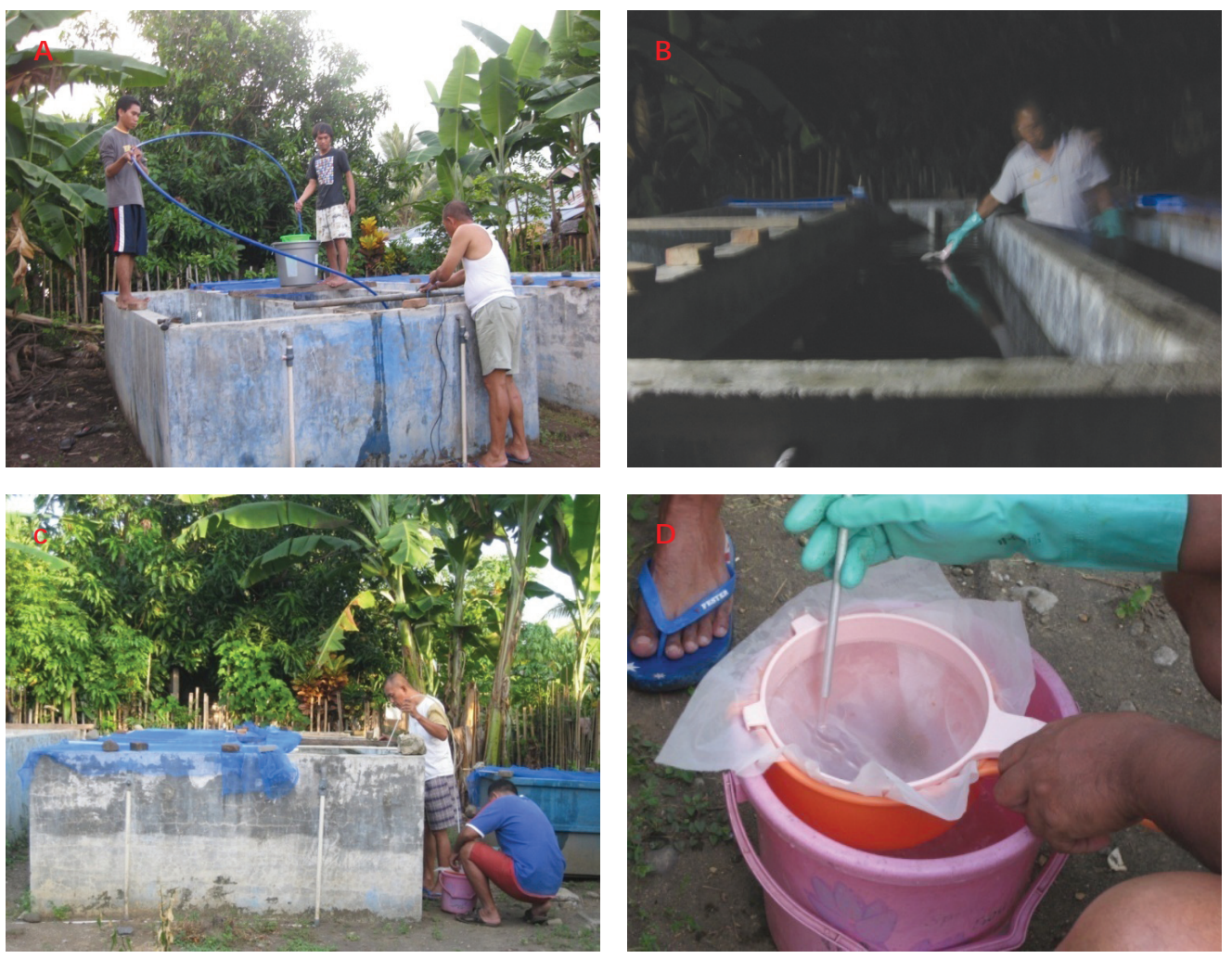

Gambar 1. Beberapa teknik pemanenan rotifer. Memompa air dari kedalaman 10-15 cm dengan pompa celup (A); Menarik jaring plankton pada permukaan (B); Menyipon dari lapisan permukaan (C); Penyaringan air hasil penyiponan (D)

Figure 1. Several rotifer harvest techniques. To pump water from $10-15 \mathrm{~cm}$ depth by submersible pump (A); To pull plankton net at surface layer (B); Siphoning surface layer (C); Screening the sucked water (D) 


\section{HASIL DAN BAHASAN}

\section{Mekanisasi Sistem Panen}

Awalnya dipahami bahwa populasi rotifer dalam medium kultur terdistribusi dengan baik sampai kedalaman lebih kurang $30 \mathrm{~cm}$. Oleh karena itu, pemanenan dilakukan dengan memompa air kolam dari lapisan 10- $20 \mathrm{~cm}$ menggunakan pompa celup (Gambar 1A). Air dari pompa tersebut disaring secara berlapis menggunakan ember plastik 10 dan 50 liter yang diberi jaring berukuran mata berturutturut $100 \mu \mathrm{m}$ dan $40 \mu \mathrm{m}$. Hal ini dimaksudkan agar dapat memisahkan rotifer dari partikel berukuran $>100 \mu \mathrm{m}$ dan $<40 \mu \mathrm{m}$. Teknik ini memberikan hasil yang kurang memuaskan, karena kecepatan penyaringan cukup tinggi, sehingga mengurangi efektivitas dan efisiensi penyaringan. Selain itu, jumlah air yang tersedot relatif banyak sehingga medium kultur mengalami pengadukan cukup tinggi, dan menghambat pertumbuhan rotifer selanjutnya.

Setelah dilakukan pengamatan kepadatan rotifer secara vertikal (pada beberapa kedalaman), diketahui bahwa kepadatan rotifer yang sangat tinggi terjadi pada lapisan permukaan. Selanjutnya diterapkan teknik pemanenan yang lain, yaitu menarik jaring plankton berukuran mata $40 \mu \mathrm{m}$ dan berdiameter $25 \mathrm{~cm}$, secara horizontal dan berulang- ulang pada lapisan $0-10 \mathrm{~cm}$ di permukaan kolam (Gambar 1B). Hasilnya cukup memuaskan dilihat dari jumlah hasil panennya. Akan tetapi mutu produk rotifernya kurang baik, karena tercampur partikel lain yang berukuran $>40 \mu \mathrm{m}$. Penarikan jaring plankton yang berulang-ulang, juga menimbulkan goncangan yang cukup berarti pada medium kultur, sehingga menghambat pertumbuhan rotifer selanjutnya.

Berdasarkan hasil ujicoba teknik pemanenan pertama dan kedua, disimpulkan bahwa untuk mempertahankan kontinuitas produksi rotifer yang optimal, selain input 1 kg ikan mentah sekali dalam 2 minggu, kestabilan air dalam kolam, dan jumlah panen yang seimbang, yaitu yang mempertahankan jumlah rotifer dalam kolam pada tingkat yang memberikan pertumbuhan populasi maksimum, adalah faktor- faktor yang perlu diperhatikan. Teknik pemanenan yang diujicobakan kemudian, diselaraskan dengan kedua faktor tersebut (Gambar 1C). Teknik tersebut terdiri atas menyipon (menyedot) air kolam hanya dari lapisan 0-1 cm di permukaan yang kepadatan rotifernya tertinggi, dan menyaringnya secara berlapis dengan jaring berukuran mata, 1.000 $\mu \mathrm{m}$ dan $20 \mu \mathrm{m}$. Prinsip mekanisasi sistem panen ini adalah memanfaatkan gaya gravitasi dan tegangan permukaan zat cair. Dengan adanya perbedaan jarak vertikal dari ujung atas dan ujung bawah pipa sifon, akan menimbulkan gaya gravitasi yang dapat digunakan untuk mengalirkan (menyedot) lapisan permukaan air kolam ke unit penyaringan. Peningkatan populasi rotifer pada lapisan permukaan $(0-0,5 \mathrm{~cm})$ akan meningkatkan tegangan permukaan air kolam, sehingga penyedotan lapisan yang padat rotifer tersebut menjadi semakin efektif. Hasil ujicoba ini cukup baik, karena memberikan perbaikan yang bermakna, yaitu; (1) Meningkatkan efektivitas, kecepatan, dan kestabilan medium kultur (tidak menimbulkan goncangan yang berarti) pada saat pemanenan; (2) Meningkatkan ketepatan perkiraan kepadatan rotifer yang perlu dipertahankan agar kontinuitas pertumbuhan rotifer tetap optimal.

Pengoperasian sejumlah unit sifon secara terintegrasi diupayakan sebagai strategi untuk meningkatkan efektivitas, kecepatan, dan kestabilan pemanenan. Mekanisasi tersebut, ditempuh dengan penggunaan sistem banyonet yang berfungsi mempertahankan ujung atas pipa sifon tepat berada pada permukaan air kolam, sehingga memungkinkan pengoperasian beberapa unit sifon secara simultan. Hasil penyedotannya kemudian diintegrasikan melalui sebuah pipa yang diarahkan ke satu unit penyaringan.

Struktur mekanisasi sistem pemanenan rotifer yang berhasil dirancang terdiri atas dua bagian utama, yaitu unit sifon dan unit saringan (Gambar 2). Sebanyak 4 unit sifon cukup efektif dioperasikan secara simultan pada kolam berukuran panjang $5 \mathrm{~m}$, lebar $1 \mathrm{~m}$, dan tinggi 1 m. Output keempat unit sifon diintegrasikan pada sebuah pipa paralon berdiameter 1,25 $\mathrm{cm}$ yang ditempatkan dengan kemiringan $10^{\circ}$ ke arah unit saringan.

Anjungan sifon ditempatkan dan bertumpu pada tepi atas dinding kolam, dan dilengkapi dengan sistem banyonet untuk menempatkan ujung atas sifon, yaitu pipa aluminium berdiameter 0,7 cm (Gambar 3A). Ujung pipa aluminium harus ditempatkan sedemikian rupa agar selain air, sifon juga dapat menyedot udara pada permukaan air kolam. Hal ini dimaksudkan untuk mengefektifkan penye- 
A

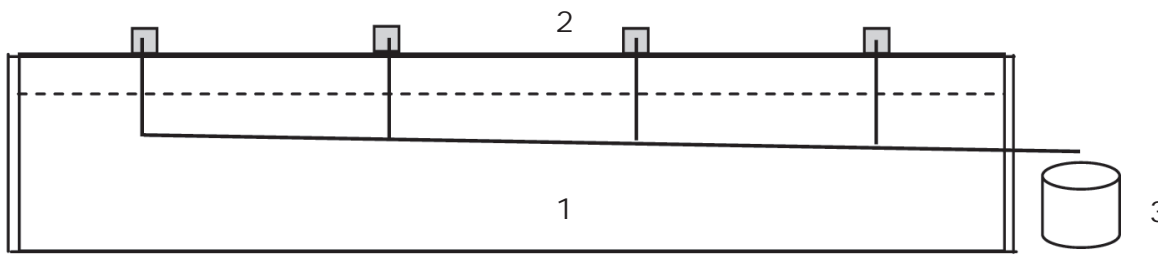

1

B

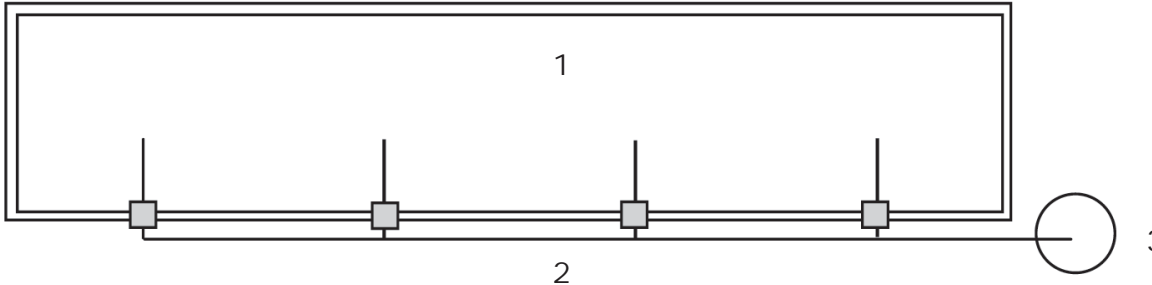

Gambar 2. Struktur alat panen rotifer; tampak samping (A), tampak atas (B), kolam (1), unit sifon (2), dan unit saringan (3)

Figure 2. Structure of the apparatus for harvest rotifer; side view (A), top view (B), pond (1), siphon unit (2), screening unit (3)

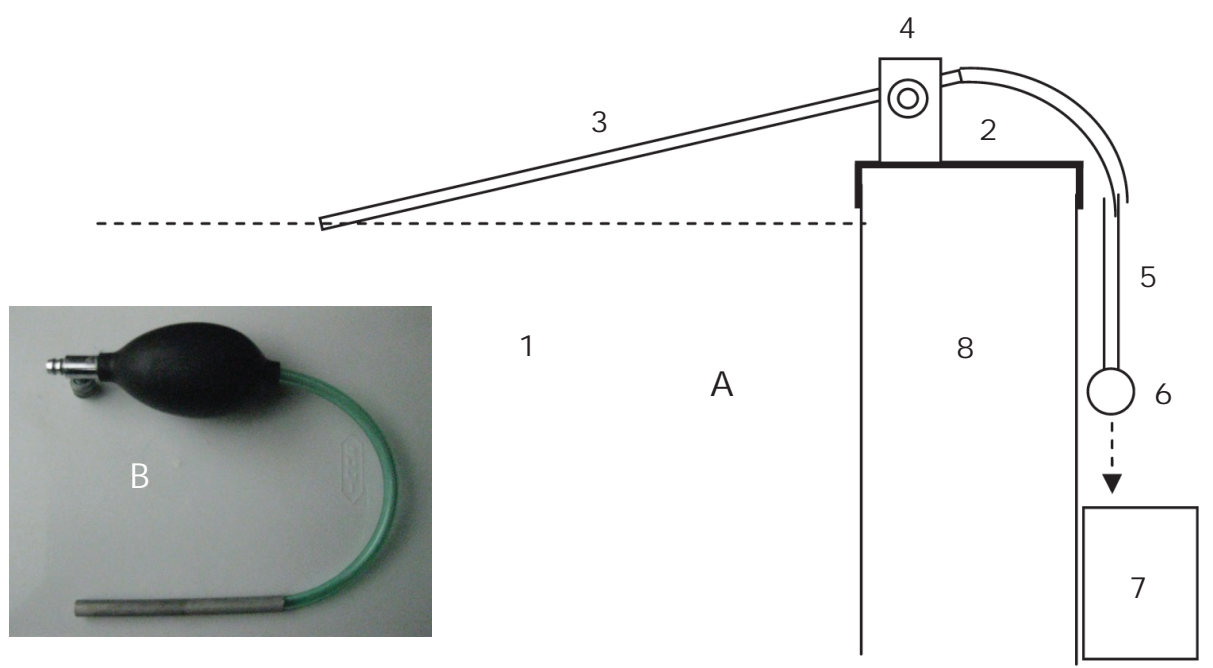

Gambar 3. Ilustrasi unit sifon (A) dan foto alat starter (B). Kolam (1), anjungan sifon (2), pipa sifon (3), sistim banyonet (4), selang sifon (5), pipa penghubung (6), unit saringan (7), dan dinding kolam (8)

Figure 3. Illustration of siphon unit ( $A$ ) and photograph of the starter (B). Pond (1), siphon platform (2), siphon pipe (3), banyonet system (4), siphon hose (5), connecting pipe (6), screening unit (7), and pond wall (8)

dotan lapisan permukaan air kolam yang memiliki tegangan permukaan cukup tinggi karena adanya populasi rotifer yang padat. Untuk menghasilkan gaya gravitasi yang dapat menyedot air pada lapisan permukaan kolam dengan efektif, jarak tegak lurus antara permukaan air kolam dan ujung bawah selang sifon dipertahankan pada $840 \mathrm{~cm}$. Untuk menjalankan unit sifon digunakan alat starter berupa pompa sedot dari karet (Gambar 3B). 
Unit saringan (Gambar 4) terdiri atas sebuah anjungan untuk menempatkan saringan berlapis 3, dengan ukuran mata jaring $1.000 \mu \mathrm{m}$, $100 \mu \mathrm{m}$, dan $20 \mu \mathrm{m}$ berturut- turut dari lapis pertama sampai lapis ketiga. Setiap jenis saringan dibuat sebanyak 3 unit, sehingga dapat digilir untuk mempertahankan kontinuitas pengoperasian sifon. Air hasil saringan ditampung dalam ember dan secara bertahap dikembalikan ke dalam kolam.

\section{Ujicoba Pengoperasian}

Setelah melalui tahapan perbaikan desain dan konstruksi, mekanisasi sistem panen pada kultur massal rotifer diujicobakan. Beberapa aspek penting yang perlu dikemukakan sehubungan dengan ujicoba tersebut, adalah sebagai berikut:

\section{Penetapan Waktu Panen}

Pemanenan dilaksanakan berdasarkan hasil pemantauan kepadatan rotifer pada lapisan 0- $1 \mathrm{~cm}$ di permukaan kolam. Salah satu hasil pelaksanaan pemantauan sampai pada jam ke- 32 diberikan pada Tabel 1. Dengan data hasil pemantauan tersebut dan menggunakan nilai daya dukung $\left(P_{m}=1.280 \mathrm{sel} / \mathrm{mL}\right)$ yang merupakan pembulatan dari rata- rata beberapa nilai kepadatan maksimum, diperoleh hasil analisis regresi dari bentuk linier model pertumbuhan logistik, sebagai berikut:

$$
\mathrm{Y}=4,715-0,132 \mathrm{t}
$$

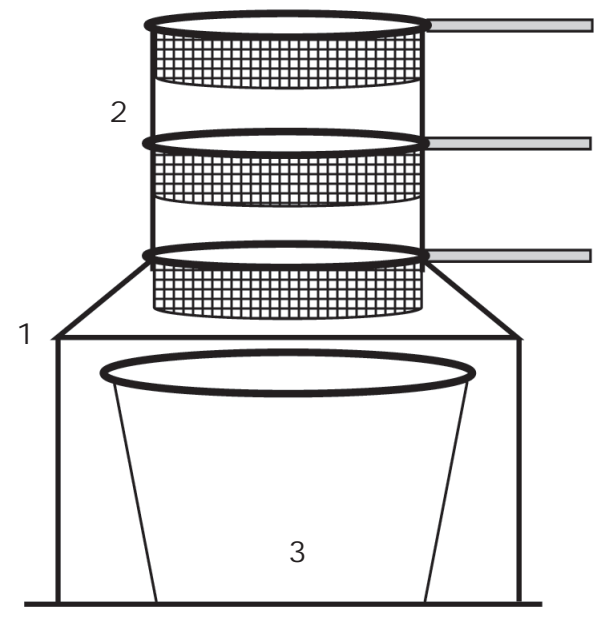

Gambar 4. Ilustrasi unit saringan. Anjungan (1), saringan (2), dan ember penampung (3)

Figure 4. Illustration of screening unit. Platform (1), screens (2), and container (3)

Tabel 1. Kepadatan rotifer pada lapisan permukaan kolam

Table 1. Rotifer density on the pond surface layer

\begin{tabular}{|c|c|c|}
\hline $\begin{array}{l}\text { Waktu (jam) } \\
\text { Time (hour) }\end{array}$ & $\begin{array}{c}\text { Kepadatan }(\mathrm{sel} / \mathrm{mL}) \\
\text { Density }(\text { cell } / \mathrm{mL})\end{array}$ & $\operatorname{Ln}\{(P m / P t)-1\}$ \\
\hline 0 & 14 & 4.50 \\
\hline 8 & 29 & 3.76 \\
\hline 16 & 75 & 2.78 \\
\hline 24 & 207 & 1.65 \\
\hline 28 & 342 & 1.01 \\
\hline 32 & 565 & 0.24 \\
\hline
\end{tabular}


Dengan demikian, nilai parameter $r=0,132$ dan $\mathrm{ti}=35,99$. Pemetaan model pertumbuhan populasi rotifer dengan nilai parameter tersebut, menghasilkan kurva pertumbuhan seperti pada Gambar 5.

Berdasarkan kurva pertumbuhan tersebut, kepadatan maksimum diperkirakan terjadi pada jam ke-96, dan pada jam ke- 60 kecepatan pertumbuhan akan mengalami penurunan yang drastis, sehingga ditetapkan panen dapat dilakukan pada jam ke-56, yaitu ketika kepadatan rotifer diperkirakan mencapai 1.195 $\mathrm{sel} / \mathrm{mL}$. Sambil menunggu waktu panen tersebut pemantauan kepadatan rotifer terus dilakukan dan hasilnya secara langsung dipetakan pada kurva pertumbuhan. Pada saat panen, hasil pemantauan menunjukkan kepadatan rotifer sebesar $1.215 \mathrm{sel} / \mathrm{mL}$.

Dalam teori hasil maksimum lestari (Clark, 1976; Weatherley, 1972; Schaefer, 1957), disimpulkan bahwa produksi maksimum dari suatu populasi (renewable resources) dapat diperoleh dengan cara mempertahankan ukuran populasi pada level $\mathrm{P}_{\mathrm{m}} / 2$. Berdasarkan pemahaman tersebut, maka panen dilakukan sampai kepadatan rotifer dalam kolam turun pada level sekitar $600 \mathrm{sel} / \mathrm{mL}$. Penetapan siklus panen berikutnya juga mengikuti prosedur yang sama (Gambar 6). Jika hasil pemantauan kepadatan rotifer bergeser jauh dari kurva pertumbuhan, maka dilakukan penyesuaian dengan menggunakan beberapa nilai $\mathrm{P}_{\mathrm{m}}$ hingga mendapatkan kecocokan yang baik antara data hasil pantauan dengan kurva pertumbuhannya.

Pada siklus panen kedua, hasil pemantauan kepadatan rotifer bergerak naik mengikuti kurva pertumbuhan dengan baik, sehingga pada jam ke- 78 telah dapat ditetapkan waktu panennya, yaitu pada jam ke- 106 (50 jam dari panen sebelumnya) dengan perkiraan kepadatan rotifer sebesar $1.269 \mathrm{sel} / \mathrm{mL}$, dan kemudian hasil pemantauan memberikan nilai $1.292 \mathrm{sel} / \mathrm{mL}$. Hasil pemantauan dalam siklus ketiga, awalnya cukup dekat dengan kurva pertumbuhan sehingga pada jam ke- 136 telah ditetapkan untuk panen pada jam ke- 156 (50 jam dari panen sebelumnya) dengan perkiraan kepadatan rotifer sebesar $1.262 \mathrm{sel} / \mathrm{mL}$. Namun hasil pemantauan pada jam ke- 144 dan 152 memperlihatkan penurunan yang berarti. Meskipun panen tetap dapat dilakukan sesuai rencana, tetapi parameter model pertumbuhan perlu disesuaikan untuk keperluan pemantauan selanjutnya. Dari hasil analisis menggunakan beberapa nilai $\mathrm{P}_{\mathrm{m}}$ didapatkan kecocokan yang baik pada $P_{m}=1.220 \mathrm{sel} / \mathrm{mL}$, dengan pasangan nilai $r=0,133$ dan $\mathrm{ti}=35,13$.

\section{Produksi Rotifer dan Kecepatan Panen}

Secara sederhana produksi rotifer diukur dalam gram bobot basah dengan tingkat ketelitian 0,01 g. Kecepatan panen diukur dengan pendekatan membagi jumlah air yang tersedot (liter) dengan lama waktu penyedotan (jam) yang dinyatakan sebagai kecepatan sifon

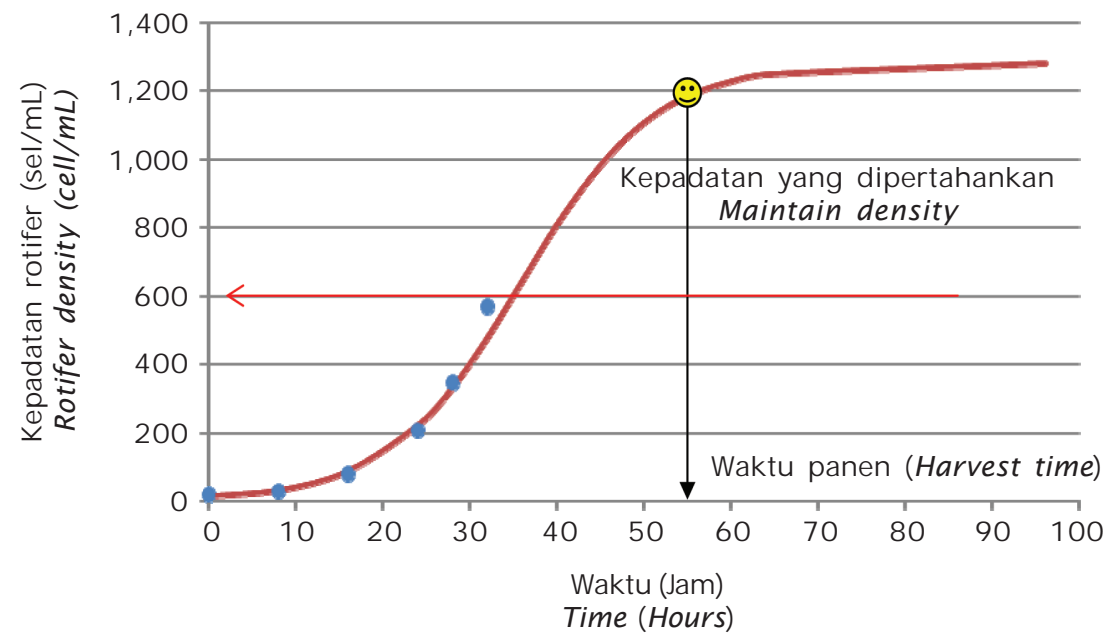

Gambar 5. Pertumbuhan populasi rotifer pada lapisan permukaan kolam

Figure 5. Population growth of rotifer on the pond surface layer 


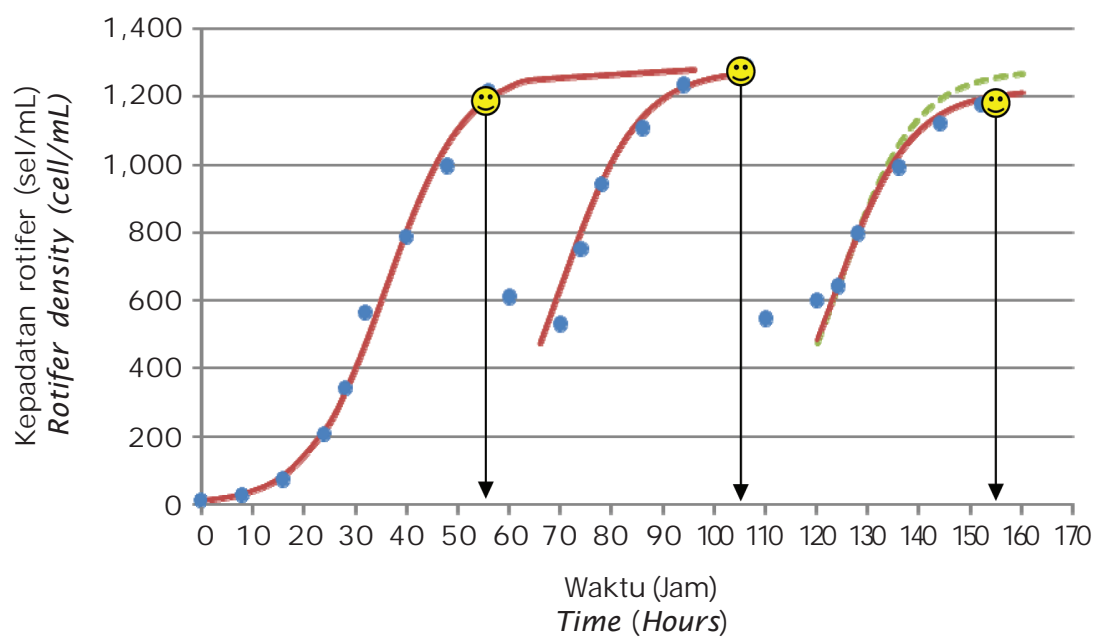

Gambar 6. Penggunaan kurva pertumbuhan dalam pemantauan kepadatan rotifer dan penetapan waktu panen

Figure 6. The application of growth curve in rotifer density monitoring and harvest time determination

(KapSi). Dari pelaksanaan uji coba sebanyak 3 siklus panen diperoleh hasil seperti pada Tabel 2.

Hasil tersebut menunjukkan bahwa terjadi peningkatan produksi karena siklus panen cenderung semakin intensif, di mana dalam waktu sekitar seminggu (160 jam) dapat dilakukan 3 kali panen dengan hasil total biomassa rotifer $716 \mathrm{~g}$. Hal ini diduga berhubungan erat dengan penggunaan model pertumbuhan (Gambar 6) sebagai acuan dalam menentukan waktu panen dan ukuran populasi rotifer yang harus dipertahankan untuk mendorong terjadinya pertumbuhan maksimum. Proses panen yang berlangsung tanpa menimbulkan goncangan yang berarti pada air kolam juga dipahami sebagai faktor yang menunjang hal tersebut.

Kecepatan pemanenan juga semakin baik, di mana sebelum mekanisasi, panen berlangsung selama \pm 4 jam, dengan jumlah air yang tersaring rata- rata 40 liter. Peningkatan

Tabel 2. Produksi dan kapasitas sifon dari 3 siklus panen

Table 2. Production and siphoning capacity from 3 harvest cycles

\begin{tabular}{|c|c|c|c|c|}
\hline $\begin{array}{l}\text { Siklus panen } \\
\text { Harvest cycle }\end{array}$ & $\begin{array}{l}\text { Produksi } \\
\text { Production } \\
\text { (g) }\end{array}$ & $\begin{array}{l}\text { Lama panen } \\
\text { Harvest range }\end{array}$ & $\begin{array}{c}\text { Jumlah air } \\
\text { Water quantity } \\
\text { (L) }\end{array}$ & $\begin{array}{c}\text { Kapasitas sipon } \\
\text { (ㄴ/jam) } \\
\text { Siphon capacity } \\
\text { (L/hour) }\end{array}$ \\
\hline I & 246 & $\begin{array}{l}2 \text { jam } 10 \text { menit } \\
2 \text { hours } 10 \text { minutes }\end{array}$ & 52 & 24.00 \\
\hline II & 232 & $\begin{array}{l}2 \text { jam } 20 \text { menit } \\
2 \text { hours } 20 \text { minutes }\end{array}$ & 57 & 24.43 \\
\hline III & 238 & $\begin{array}{l}2 \text { jam } 15 \text { menit } \\
2 \text { hours } 15 \text { minutes }\end{array}$ & 54 & 24.00 \\
\hline $\begin{array}{c}\text { Rata-rata } \\
\text { Average }\end{array}$ & 238 & $\begin{array}{l}2 \text { jam } 15 \text { menit } \\
2 \text { hours } 15 \text { minutes }\end{array}$ & 54.33 & 24.14 \\
\hline
\end{tabular}


terjadi karena dengan sistem banyonet, kestabilan posisi ujung atas pipa sifon dapat dipertahankan, sehingga penyedotan berlangsung tanpa interupsi yang berarti. Penempatan keempat unit sifon dengan luas cakupan penyedotan yang seimbang, memungkinkan terjadinya penurunan kepadatan rotifer yang cukup merata pada seluruh permukaan kolam, sehingga meningkatkan ketepatan pemantauan dan pengontrolan kepadatan rotifer yang harus dipertahankan. Integrasi pengoperasian seluruh sifon dengan satu unit saringan berlapis 3 , selain memudahkan pengontrolan sehingga meningkatkan efisiensi penggunaan tenaga kerja, juga memberikan produksi biomassa rotifer yang lebih berkualitas.

\section{KESIMPULAN}

Mekanisasi sistem panen yang tidak menimbulkan goncangan pada medium kultur, panen yang hanya difokuskan pada lapisan permukaan kolam, dan mekanisme penggunaan model pertumbuhan populasi sebagai acuan dalam mengontrol siklus panen dan ukuran populasi rotifer yang dipertahankan dalam kolam, memberikan dampak positif terhadap proses kesinambungan pertumbuhan populasi rotifer yang optimal.

\section{UCAPAN TERIMA KASIH}

Penelitian ini merupakan bagian dari kegiatan Program Insentif Riset Dasar RD- 20100144 yang didanai dari Program Insentif Kementerian Negara Riset dan Teknologi, No. 104/ RD- DF/ D.PSIPTN/Insentif/ PPK/ l/ 2010. Untuk itu, penulis menyampaikan terima kasih sebesar- besarnya kepada semua pihak terkait dalam Program Insentif tersebut.

\section{DAFTAR ACUAN}

Bowman, B.P., Snell, T.W., \& Cochrane, B.J. 1990. Isolation and purification of glutathione Stransferase from Brachionus plicatilis and B. calyciflorus (rotifera). Comp. Biochem. Physiol., 95B(3): 619- 624.

Clark, C.W. 1976. Bioeconomics. The optimal management of renewable resources. John Wiley \& Sons, New York, 352 pp.

Hara, K., Arano, H., \& Ishihara, T. 1984. Some enzymatic properties of alkaline proteases of the rotifer Brachionus plicatilis. Bull. Jap. Soc. Sci. Fish, 50(9): 1,611- 1,616.

Klusemann, Kleinow, W., \& Peters, W. 1990. The hard parts (trophi) of the rotifer mastax do contain chitin evidence from studies on Brachionus plicatilis. Histochemistry, 94: 277- 283.

Lubzens, E., Rothbard, S., Blumenthal, A., Kolodny, G., Perry, B., Olund, B., Wax, Y., \& Farbstein. 1989. Possible use of B. plicatilis as food for freshwater cyprinid larvae. Aquaculture, 60: 143- 155.

Nogrady, T., Wallace, R. L., \& Sneel, T.W. 1993. Rotifera. Biology, ecology and systematic. SPB. Academic Publishing Netherland, 145 pp.

Pauly, D. 1984. Some simple methods for the assessment of tropical fish stocks. FAO Fisheries Technical Paper, 52 pp.

Rumengan, I.F.M. 1997. Marine rotifers (Brachionus spp.) as a biocapsule for larvae of various marine fauna. Warta Wiptek, 19: 34- 43.

Rumengan, I.F.M., Warouw, V., \& Hagiwara, A. 1998. Morphometry and resting egg production potential of the tropical ultraminute rotifer Brachionus rotundiformis (Manado strain) fed different algae. Bull. Fac. Fish. Nagasaki Univ. Nos., 79: 31- 36.

Schaefer, M.B. 1957. A study of the dynamics of fishery for yellowfin tuna population of the Eastern Pasific ocean. Bull. Inter-Am Trop. Tuna Comm., 2: 247- 268.

Suga, K., Mark Welch, D., Tanaka, Y., Sakakura, Y., \& Hagiwara, A. 2007. Analysis of expressed sequence tags of the cyclically parthenogenetic rotifer Brachionus plicatilis. PLOSONE (8):e671.doi:10.1371/ journal.pone.0000671.

Wallace, R.L. \& Snell, T.W. 1991. Rotifer. Ecology and classification of North American freshwater invertebrates. Academik Press. Inc., p. 187- 207.

Weatherley, A.H. 1972. Growth and ecology of fish population. Academic Press. London, $293 \mathrm{pp}$.

Yoshinaga, T., Minegishi, Y., Rumengan, I.F.M., Kaneko, G., Furukawa, S., Yanagawa, Y., Tsukamoto, K., \& Watanabe, S. 2004. Molecular phylogeny of the rotifers with two Indonesian Brachionus lineages. Coastal Marine Science, 29(1): 45- 56. 